\title{
Penegakkan Etika Profesional Pemeriksa BPK Untuk Peningkatan Kualitas Pengelolaan Keuangan Negara
}

\section{Enforcement of Professional Ethics for BPK Examiners to Improve the Quality of State Financial Management}

\author{
Dian Kusuma Wardhani*, Erina Sudaryati
}

Universitas Airlangga Surabaya, Indonesia

The purpose of this study was to analyze the strategy of upholding the professional ethics of BPK auditors. This research is qualitative research using a descriptive method where the researcher describes the data and analyzes the data. Based on the documentary research, it is known that divine awareness built from religiosity forms the moral and awareness of BPK examiners to enforce the code of ethics to guide BPK examiners to always behave ethically when facing ethical dilemmas. In the end, this study provides seven strategies or recommendations as an effort to uphold the professional ethics of the BPK auditors, namely moral management skills, trustworthy BPK auditors, adequate legal knowledge, comprehensive understanding of professional code of ethics, loving nature, acknowledging any unethical practice and not trying to find fault.

OPEN ACCESS

ISSN 2548-3501 (online)

Edited by:

Eny Maryanti

Reviewedby:

Supriyati.

${ }^{*}$ Correspondence:

Dian Kusuma Wardhani

dian.kusuma.wardhani-

2019@unair.ac.id

Received: 15 Desember 2020

Accepted: 20 Janaury 2020

Published: 31 January 2020

Citation:

Wardani and Sudaryati(2021)

Penegakkan Etika Profesional

Pemeriksa BPK Untuk

Peningkatan Kualitas

Pengelolaan Keuangan Negara
Keywords: BPK auditors, code of ethics, ethics, accounting.

Penelitian ini bertujuan menganalisis strategi guna menegakkan etika profesional pemeriksa BPK. Penelitian ini merupakan kualitatif dengan metode deskriptif dimana peneliti mendeskripsikan kemudian menganalisa temuan penelitian. Dari documentary research diketahui bahwa kesadaran ketuhanan yang dibangun dari religiusitas membentuk moral dan kesadaran pemeriksa BPK untuk menegakkan kode etik sehingga menuntun pribadi pemeriksa BPK agar selalu bersikap etis ketika dihadapakan pada dilema etis. Penelitian ini memberikan tujuh rekomendasi sebagai upaya menegakkan etika profesional pemeriksa BPK yaitu, kemampuan manajemen moral, menjadi pemeriksa BPK yang amanah, memiliki pengetahuan hukum yang cukup, memiliki pemahaman kode etik profesi yang komprehensif, memiliki kecintaan pada alam, mengenali setiap praktik tidak etis dan tidak berusaha mencari-cari kesalahan.

Keywords: pemeriksa BPK, kode etik, etika, akuntansi. 


\section{PENDAHULUAN}

Hubungan antara pemerintah dan rakyat merupakan salah satu bentuk keagenan dimana rakyat adalah principal yang kepentingannya diwakilkan oleh DPR, DPD, DPRD dan agent diwakilkan oleh pemerintah beserta semua aparat pendukungnya. Teori keagenan berpandangan bahwa agent cenderung berusaha bertindak sesuka hati untuk memaksimalkan keuntungan pribadinya dengan menyembunyikan informasi penting dari principal sehingga terjadi asimetri informasi yang menjadi dasar pemicu konflik keagenan (Jensen dan Meckling, 1976). Demi menjamin kewajaran informasi yang disajikan pemerintah, dibutuhkan pihak ketiga yang indepeden untuk memeriksa kewajaran serta kebenaran informasi tersebut sehingga rakyat menjadi yakin dan percaya bahwa pemerintah benar-benar bertanggung jawab dengan baik atas pengelolaan keuangan negara. Pihak independen yang melaksanakan fungsi pemeriksaan ini adalah Badan Pemeriksan Keuangan (BPK) RI sebagai auditor eksternal pemerintah Indonesia.

Kepercayaan tinggi publik pada BPK RI sempat tercoreng karena adanya praktik jual beli opini yang melibatkan pegawai BPK, yakni Ali Sadli (Kepala Sub Auditorat III Auditorat Keuangan Negara BPK) dan Rochmadi Saptogiri (Pemeriksa BPK) pada tahun 2017, dimana Ali menerima uang Rp 240 juta dari pejabat Kemenderian Desa Pembangunan Daerah Tertinggal dan Transmigrasi (Kemendes) untuk diberikan pada Rochmadi agar mau memberikan opini Wajar Tanpa Pengecualian (WTP) pada Laporan Hasil Pemeriksaan (LHP) atas Laporan Keuangan Kemendes tahun anggaran 2016 (Kumparan, 2017). Pada maret 2018, Ali Sadli dijatuhi hukuman enam tahun penjara dan denda Rp 250 juta, sementara Rochmadi Saptogiri mendapat hukuman tujuh tahun penjara (Gabrillin, 2017). Kasus Ali dan Rochmadi merupakan salah satu bukti rapuhnya integritas pemeriksa BPK, jika dibiarkan hal ini dapat berakibat pada terjadinya krisis profesi auditor pemerintah di lingkup BPK RI karena lingkungan atau budaya organisasi akan berpengaruh pada perilaku etis personal individu (Sirajudin, 2013).

BPK RI selalu berupaya berbenah diri untuk mendapatkan kepercayaan publik kembali dan menjadi lembaga pemeriksa terpercaya, untuk itu BPK mengusung slogan accountability for all dengan maksud membangun kerangka kerja baru sebagai bentuk komitmen perbaikan, dan mendorong kesadaran masyarakat akan arti penting akuntabilitas keuangan negara (BPK RI, 2019). Kepercayaan publik ini dapat tercipta dari pelayanan prima yang diberikan oleh BPK jika telah menegakkan prinsip-prinsip etika profesinya (Nikmatuniayah, 2015). Sejalan dengan gagasan tersebut, demi terciptanya penegakkan kode etik dengan tujuan peningkatan kesadaran pemeriksa, diterbitkan Peraturan BPK RI Nomor 4 Tahun 2018 tentang Kode Etik BPK sebagai pedoman kode etik baru dengan tiga nilai dasar utama yaitu independensi, integritas dan profesionalisme. Ketiga nilai tersebut harus senantiasa melekat pada diri setiap anggota BPK dan pemeriksa serta harus dipatuhi selama memenuhi kewajibannya demi menjaga martabat, kehormatan, citra dan kredibilitas organisasi BPK RI.

Faktor sumber daya manusia adalah kunci sukses dalam pemeriksaan BPK sekaligus penyebab utama terjadinya kecurangan apabila individu tersebut tidak berintegritas (Irawan dan McIntyre-Mills, 2016). Setiap pemeriksa BPK telah diambil sumpah jabatan saat pelantikannya dan dituntut menepati janji yang telah diucapkan tersebut, dimana saksi ikrar sumpah tersebut bukan hanya manusia saja tetapi juga Tuhan Yang Maha Esa, oleh karena itu hendaknya dalam mengemban amanahnya pemeriksa BPK selalu berpedoman pada kode etik dengan berorientasi kuat pada pelayanan publik sebagai ciri utama profesi pemeriksa BPK (Briando dan Purnomo, 2019).

Etika profesi sendiri adalah studi tentang benar atau salah, baik atau buruk yang berkaitan dengan perilaku seseorang dalam menjalanan profesinya (Lamba et al., 2020). Berdasarkan pemikiran tersebut pemeriksa BPK membutuhkan etika profesi untuk menjaga kepercayaan masyarakat akan kualitas pemeriksaan yang dilakukannya sebagai bentuk pertanggung jawaban profesinya kepada publik (Menzel dan White, 2015). Kesadaran menegakkan etika profesi diharapkan mampu mendorong pemeriksa BPK mencapai tujuan profesi mereka dan juga tujuan akhir yang holistik yaitu menggapi ridho illahi untuk kesuksesan akhirat (Briando, Triyuwono dan Irianto, 2017; Sylvia, 2014).

Ciri yang menjadi pembeda antara profesi dan pekerjaan adalah adanya independensi dan kesadaran akan tanggung jawabnya untuk kepentingan publik dalam suatu profesi. Pada kondisi seorang pemeriksa BPK sudah tidak lagi independen dan tidak lagi berorientasi untuk melayani masyarakat, maka dengan mudah praktik kecurangan atau pelanggaran etika terjadi. Pada saat independensi dan oritentasi public interest itu hilang, artinya pemeriksa BPK tidak lagi dianggap sebagai profesi tetapi berganti menjadi apa yang disebut dengan pekerjaan, karena profesi butuh etika professional sedangkan pekerjaan tidak. Menjadi seorang pemeriksa BPK yang profesional, independensi dan berorientasi pada kepentingan publik adalah kewajiban dan tidak bisa dikompromikan dalam memenuhi pekerjaannya (Duska, 2007). Penelitian sebelumnya terkait kode etik BPK terbatas hanya membahas persepsi pemeriksa BPK terhadap implementasi kode etik yang telah dilaksanakan dan evaluasi peran kode etik tersebut terhadap kemungkinan terjadinya tindak kecurangan selama proses pemeriksaan (Tatiara dan Astuti, 2019; Sitanala, 2019).

Termotivasi dari keterbatasan penelitian sebelumnya, adanya fenomena jual beli opini pemeriksa BPK, serta sedikitnya penelitian terkait pemeriksa BPK yang mendapat perhatian dari peneliti dibandingkan dengan penelitian tentang auditor publik atau pajak membuat penelitian tentang pemeriksa BPK menarik 
untuk diteliti. Berbeda dengan penelitian terdahulu, penelitian ini mencoba memahami penyebab perilaku etis maupun tidak etis pemeriksa BPK kemudian sebagai respon terhadap kesenjangan tersebut dirumuskan rekomendasi-rekomendasi yang diharapkan dapat memperbaiki kesenjangan dalam praktik pemeriksaan. Berdasarkan pemaparan sebelumnya, maka pertanyaan penelitian ini adalah upaya apa yang dapat dilakukan demi menegakkan etika profesional pemeriksa BPK untuk meningkatkan kualitas pengelolaan keuangan negara, dan menjawab pertanyaan tersebut maka tujuan penelitian ini adalah mengeksplorasi upaya yang dapat dilakukan oleh pemeriksa BPK guna menegakkan etika profesional untuk peningkatan kualitas pengelolaan keuangan negara.

\section{METODE}

Penelitian ini merupakan penelitian kualitatif, yaitu penelitian tak terstruktur yang bertujuan untuk memperolehan pemahaman atas suatu fenomena (Bilgin, 2017). Jenis data penelitian ini adalah data sekunder dari sumber-sumber berupa artikel penelitian sebelumnya, bukubuku, berita elektronik dan informasi lainnya yang relevan dengan topik penelitian. Metode yang digunakan dalam penelitian ini ialah documentary research, dimana peneliti mencari referensi berupa penelitian sebelumnya, buku dan dokumen lain yang relevan dengan topik penelitian ini kemudian mengorganisasikannya dan membuat ringkas tertulis atas temuan yang diperoleh (Creswell dan Poth, 2016). Temuan yang diperoleh selanjutnya dianalisis secara deskriptif dengan mendeskripsikan temuan dan melakukan analisa melalui pemberian pemahaman serta penjelasan atas temuan tersebut (Habsy, 2017).

\section{HASIL DAN PEMBAHASAN}

\section{Dilema Etis Pemeriksa BPK}

Faktor pendukung terciptanya tata kelola pemerintahan berkualitas tinggi menurut Noviriani, Ludigdo dan Baridwan (2018) ialah adanya pengawasan oleh lembaga legislatif, pengendalian oleh lembaga eksekutif dan juga pemeriksaan oleh BPK yang semuanya terlaksana dengan baik dan efektif. Undang-Undang Republik Indonesia Nomor 15 Tahun 2006 menjelaskan bahwa BPK RI ialah lembaga negara yang diamanatkan oleh UUD 1945 untuk melakukan pemeriksaan terhadap pemerintah baik pusat maupun daerah, lembaga negara lainnya, Bank Indonesia (BI), Badan Usaha Milik Negara dan atau Badan Usaha Milik Daerah, Badan Layanan Umum (BLU), dan lembaga lainnya yang mengelola keuangan negara, dimana proses pemeriksaannya meliputi pengindentifikasian masalah, kemudian menganalisa dan mengevaluasi secara independen, objektif serta profesional dalam menilai suatu kebenaran, keandalan, dan kredibilitas informasi pengelolaan maupun tanggung jawab keuangan negara sesuai dengan standar pemeriksaan berlaku. Hasil pemeriksaan BPK tersebut nantinya diungkap dalam Laporan Hasil Pemeriksaan (LHP) yang ditujukan kepada DPR, DPD, DPRD dan dipublikasikan untuk umum (BPK RI, 2018).

Pemerintah pusat maupun daerah selanjutnya akan menindaklanjuti LHP tersebut dan tindak lanjut atas hasil pemeriksaan harus diserahkan kepada BPK secara tertulis. Berdasarkan ketentuan tersebut dapat dikatakan bahwa BPK RI merupakan ujung tombak atau penentu dari perbaikan akuntabilitas serta transparansi informasi penyelenggaraan keuangan negara. Pemeriksa BPK harus selalu berperilaku etis, melakukan tugas dan wewenangnya sebaik mungkin untuk mewujudkan akuntabilitas pengelolaan keuangan negara tinggi sehingga tercipta tata kelola pemerintahan yang baik (Winata dan Khomsiyah, 2018; Noviriani, Ludigdo dan Baridwan, 2018).

Keputusan etis diartikan sebagai keputusan dari perspektif hukum maupun etis dapat diterima dengan baik oleh masyarakat umum (Hazgui dan Brivot, 2020). Fokus perilaku etis pemeriksa BPK adalah mengkritisi apa yang baik atau buruk dari perspektif moral, dan outcome dari perilaku etis tersebut tidak diukur dalam keuntungan material, tetapi terletak pada nilai intrinsiknya, dimana ketika seorang pemeriksa BPK berperilaku etis maka akan menghasilkan kepercayaan di lingkungan mereka dan masyarakat (Morales-Sánchez, OrtaPérez dan Rodríguez-Serrano, 2019). Tidak hanya terbatas pada pemeriksa BPK, berperilaku etis merupakan sebuah kewajiban bagi semua kompartemen auditor karena mempengaruhi kredibilitas profesinya.

Pemeriksa BPK mendasarkan perilaku etis mereka dengan berpedoman pada Peraturan BPK RI Nomor 4 Tahun 2018, yang berisi tentang kode etik sebagai pemeriksa BPK RI dan berlaku sejak 31 Desember 2018 hingga sekarang. Kode etik ini menunjukkan konsensus bersama yang dibuat dan dikodifikasi secara tertulis untuk dipatuhi serta mengikat semua aktivitas anggotanya (McKinney, Emerson dan Neubert, 2010). Setiap terjadi pelanggaran kode etik oleh pemeriksa BPK, akan dilakukan pendisiplinan oleh Majelis Kehormatan Kode Etik (MKKE) BPK RI.

BPK RI diharapkan dapat menerapkan dan menegakkan kode etik di seluruh organisasinya karena kegagalan dalam menegakkan kode etik dapat mencoreng integritas BPK RI serta berefek negatif pada integritas organisasi sektor publik Indonesia, dengan menghambat efektivitas produksi barang dan jasa publik (Syukur, 2015). Menjamin penegakkan kode etik tersebut, dibutuhkan peran penting dari seorang pemimpin dengan ikut serta mendorong kepatuhan, mengkomunikasikan dan memberi teladan pada anggotanya atas implementasi kode etik pemeriksa BPK (Lloyd dan Mey, 2010). Kode etik yang ditegakkkan dengan baik akan menciptakan lingkungan etis 
sehingga mencegah terjadinya perilaku tidak etis dan dilema etis pemeriksa BPK. Beberapa alasan kegagalan dan kesuksesan penerapan kode etik dalam suatu organisasi profesi, yaitu pada Tabel 1

\section{[Table 1 about here.]}

Berdasarkan aturan kode etik pemeriksa BPK, independensi, integritas dan profesionalisme merupakan tiga prinsip etika utama yang melekat dan mengikat seluruh pemeriksa BPK RI. Nilai utama yang dianut adalah independent untuk menegaskan bahwa BPK RI ialah lembaga independen dalam hal organisasi, legislasi, maupun anggaran, ia juga bebas dari intervensi lembaga negara lain (BPK RI, 2018). Independensi pemeriksa BPK menunjukkan sikap pemeriksa BPK dalam merespon fakta seperti bukti audit, sikap pimpinan atau pegawai selama proses pemeriksaan dimana sikap independen pemeriksa BPK tercermin jika ia bebas dan tidak memihak dalam penyusunan program, pemilihan bidang, kegiatan atau kebijakan manajerial terperiksa, serta tidak memihak ketika mengungkap fakta pemeriksaan atau pemberian rekomendasi hasil pemeriksaan (Menzel dan White, 2015). Pemeriksa BPK independen secara kelembagaan dan atau individu, baik terkait pekerjaan pemeriksaan, sikap mental serta penampilan (BPK RI, 2016). Pemeriksa BPK yang tidak independen, tidak jujur serta tidak objektif ketika mengungkap fakta karena berpihak pada agent (pemerintah, BUMN, dll) akan merugikan pihak pemakai jasanya yaitu principal (DPR, DPD, DPRD, masyarakat, LSM, investor dan kreditur) dan akhirnya pendapatnya juga tidak memiliki arti apapun (Ulum, 2005). Independensi pemeriksa BPK yang terjaga dengan baik akan meningkatkan kredibilitas laporan hasil pemeriksaan (LHP) atau dapat dikatakatan independensi menentukan kualitas pemeriksaan ( Jamal dan Sunder, 2011). Selain itu, kualitas tinggi pemeriksaan tercipta apabila pemeriksa BPK mampu meminimalisir kesalahan dalam pemeriksaannya (Lamba et al., 2020).

Integritas diartikan dalam Peraturan BPK RI Nomor 4 Tahun 2018 Pasal 1 Ayat 9 sebagai sifat, mutu, dan keadaan yang menggambarkan kesatuan penuh dari sifat kerja keras, jujur, serta kompentensi memadai. Prinisp integritas ini tidak hanya terbatas pada tiga sifat tersebut tetapi juga mencerminkan kewajaran serta kebenaran informasi yang disampaikan oleh agent sebagai dasar kepercayaan dalam pertimbangannya untuk menyatakan pendapat (Pasaribu dan Briando, 2019). Wahyudi (2013) menjelaskan bahwa integritas artinya bersikap tidak korup, memiliki jiwa tulus, ramah, netral, sopan, fokus pada kepentingan publik dan memiliki rasa hormat yang tinggi. Pemeriksa BPK harus membangun dan mewujudkan nilai integritas dengan selalu menunjukkan sikap jujur, objektif dan tegas ketika melakukan penilaian, pembuatan keputusan, dan penyelesaian pekerjaannya (BPK RI, 2016; Fatemi, Hasseldine dan Hite, 2020). Dengan tanggungjawab yang besar, seharusnya pemeriksa BPK memiliki integritas kuat dan baik sebelum mereka menilai integritas insitusi lain karena integritas adalah kunci kesuksesan pemeriksaannya.

Profesionalisme berarti suatu keahlian, kemampuan, serta komitmen untuk menjalankan tugas, dimana profesionalisme seorang pemeriksa BPK diwujudkan melalui praktik skeptisisme profesional selama pemeriksaan, dengan mengutamakan pertimbangan profesional dalam menilai temuan, dan melaporkan temuan tersebut pada laporan hasil pemeriksaan (Korompis, 2018). Pemeriksa BPK diharapkan mampu membangun sikap profesionalisme dengan selalu menerapkan sikap kehati-hatian, teliti, cermat dan terus berpedoman pada standar yang berlaku (BPK RI, 2016). Selain itu, pemeriksa profesional juga diharapkan dapat menjaga kompentensi profesional pribadi yang diperoleh selama mereka menempuh pendidikan formal maupun dari kegiatan wajib pengembangan professional bisa dilihat pada figure 1 (Triani, Hidayat dan Ardianto, 2020).

\section{[Figure 1 about here.]}

Skeptisme profesional, kehati-hatian dan perasaan takut mengecewakan publik adalah komponen penting yang harus dikembangkan sebagai budaya kerja dalam praktik pemeriksaan karena hal tersebut akan mengasah integritas, peningkatan independensi dan juga membangun profesionalisme pemeriksa BPK sehingga mereka tidak akan membuka pintu untuk mencoba perilaku tidak bermoral (Hazgui dan Brivot, 2020). Pemeriksa BPK yang skeptis tidak begitu cepat menerima penjelasan dari pihak terperiksa, mereka harus mengajukan pertanyaan rinci serta kritis atas setiap temuan pemeriksaan sebagi bentuk konfirmasi dan membentuk keyakinan mereka terhadap kewajaran pengelolaan keuangan negara yang dilakukan terperiksa (Lamba et al., 2020). Skeptisme profesional pemeriksa BPK ditunjukkan dengan selalu mempertanyakan sesuatu (questioning mind) serta selalu bersikap waspada pada segala kondisi pemeriksaannya yang dicurigai terdapat indikasi praktik kecurangan (Jaya dan Irene, 2016).

Pemeriksa BPK dituntut menjunjung tinggi ketiga prinsip etika dalam menjalankan fungsi pemeriksaan, namun kenyataannya tidak mudah mewujudkan sikap-sikap tersebut karena ia berada dalam lingkungan kompleks dengan beragam persepsi dan kepentingan kelompok berbeda yang seringkali berupaya menggoyahkan profesionalisme pemeriksa BPK sehingga terjadi dilema etis (Syukur, 2015). Misalnya, pemeriksa BPK mendapatkan intervensi dari “oknum” untuk tidak melaporkan temuan pemeriksaannya dengan suatu imingiming hadiah balas jasa. Intervensi tersebut tentunya akan mempengaruhi proses pemeriksaannya, karena pemeriksa BPK dihadapkan pada dua pilihan yaitu menutupi temuan dan mendapatkan imbal jasa atau melaporkan indikasi temuan 
tersebut dalam Laporan Hasil Pemeriksaannya.

Hazgui dan Brivot (2020) mengatakan bahwa, ketika terjadi dilema seperti itu biasanya individu bersangkutan akan berkonsultasi dengan rekan sejawat yang memiliki ikatan sosial kuat dengan mereka tentang bagaimana cara terbaik menghadapi klien atau situasi sulit tersebut untuk memastikan bahwa interpretasi mereka atas prinsip etika selaras dengan kode etik yang disyaratkan organisasi profesi. Oleh karena itu, sering dikatakan bahwa pengambilan keputusan etis adalah upaya kolektif karena para pemeriksa yang sedang dilema secara spontan memilih berkonsultasi dengan rekan sejawat. Masalah muncul jika rekan sejawat yang dimintai nasehatnya ini tidak memiliki integrtias tinggi, bukan tidak mungkin nantinya justru akan terjadi praktik kecurangan kelompok. Pemikiran ini mendukung West (2018) yang menyatakan bahwa secara umum kondisi lingkungan sekitar seperti budaya kerja di lingkungan organisasi atau kedekatan dengan rekan sejawat pada khususnya dapat memperkuat atau memperlemah integritas seorang pemeriksa profesional.

Kode etik BPK mempunyai keunikannya tersendiri, dimana pemeriksa BPK dilarang memberikan bimbingan teknis atas aktivitas pengelolaan keuangan pada organisasi yang diperiksanya dan hanya diperbolehkan menjelaskan temuan serta rekomendasi atas temuan pemeriksaan (Hidayat, 2019). Pemeriksa BPK yang terbukti melakukan pembimbingan teknis akan dijatuhi sanksi berupa pemberhentian keanggotaan atau pemecatan. Tindakan tersebut adalah bukti upaya tegas yang ditempuh BPK RI dalam menegakkan kode etik pemeriksa BPK.

Syukur (2015) mengatakan bahwa sejak tahun 2011, BPK RI mulai memperkenalkan sistem whistle blowing, dimana setiap pegawai BPK diwajibkan melaporkan tindakan pelanggaran kode etik oleh pegawai BPK kepada satgas (Inspektorat Utama, Biro SDM dan Direktorat Hukum), sistem ini dimaksudkan untuk mendeteksi dan menindak tegas pelanggaran kode etik di lingkup BPK RI. Satgas akan mengecek dan apabila pengaduan indisipliner tersebut terbukti maka laporan tersebut akan disampaikan ke Panitera Majelis Kehormatan Kode Etik (MKKE) BPK RI untuk diselidiki lebih lanjut dan diadili. Upaya serius BPK dalam menindak tegas pelanggaran kode etik juga dibuktikan dengan dilakukannya launching aplikasi Whistle Blowing System (WBS) pada tahun 2017 untuk mewadahi pengaduan dugaan pelanggaran yang dilakukan oleh pegawai BPK (BPK RI, 2017). Tujuan diciptakannya aplikasi ini bukanlah untuk "saling membunuh" antara sesama pegawai BPK tapi untuk menunjang efektivitas pelaksaan tugas pemeriksa BPK.

Menjadi seorang whistleblower bukanlah tak berisiko, pegawai BPK bisa saja mendapatkan tekanan dari berbagai pihak (Andrade, 2015; Culiberg dan Mihelič, 2017). Brown, Hays dan Stuebs Jr (2016) menyebutkan bahwa tekanan tersebut berupa beban perasaan terkait ancaman yang mungkin diterima nantinya sebagai konsekuensi dari melaporan pelanggaran. Tekanan yang umumnya menjadi alasan pegawai BPK untuk tetap diam dan tidak berani mengungkap kecurangan adalah ketakutan akan perlakuan tidak adil dari lingkungan sekitar, pembalasan di masa depan serta hilangannya reputasi apabila identitas dirinya terungkap ke publik (Latan, Jabbour dan de Sousa Jabbour, 2019). Semakin tinggi tekanan yang dirasakan seorang pegawai BPK, maka semakin besar kemungkinan individu tersebut untuk memilih diam (Miceli et al., 2012).

Kemauan seseorang untuk menjadi whistleblower juga bergantung pada rasionalisasi diri mereka pada saat kejadian, dimana individu tersebut akan melihat peluang dalam sumber daya pendukung seperti ketersediaan atau akses saluran pelaporan, dukungan organisasi, dan kode etik profesional (Murphy dan Free, 2016). Rasionalisasi adalah proses kognitif untuk meyakinkan diri mereka sendiri bahwa tindakan yang dilakukan sesuai dengan standar etika dan profesional (McGrath, 2017). Rasionalisasi tinggi yang dimiliki pemeriksa BPK akan meningkatkan kesediaan mereka menjadi whistleblower, karena pemeriksa BPK memiliki keyakinan dan kesadaran bahwa tindakan yang mereka ambil untuk melaporkan kecurangan sudah sesuai dengan kode etik profesi (Dellaportas, 2013).

BPK RI juga meyakinkan bahwa para pelapor tidak perlu "galau" apalagi merasa takut untuk menjadi whistleblower karena BPK RI menjamin kerahasiaan identitas pelapornya dan menjadi whistleblower adalah tindakan terpuji karena ia berusaha menegakkan keutamaan kejujuran sebagai wujud integritas profesinya (Seifert et al., 2010). BPK RI bukan lembaga yang bertujuan mencari-cari kesalahan pemerintah beserta aparatnya, tetapi merupakan sebuah lembaga negara dengan integritas tinggi dimana tujuannya ialah memberikan rekomendasi pada segala permasalahan keuangan pengelolaan negara untuk membantu pemerintah dalam mengelola keuangan negara agar terlaksana secara efektif serta efisien demi terwujudnya kesejahteraan rakyat, karenanya setiap masalah atau pemicu dilema etis pemeriksa BPk harus segera ditindak tegas dan diputus mata rantainya (Syukur, 2015).

\section{Kesadaran Ketuhanan Sebagai Upaya Peningkatan}

\section{Moral Pemeriksa BPK}

Seorang pemeriksa BPK secara terus menerus akan dihadapkan pada dilema etis nilai-nilai yang saling bertentangan (Wibowo, 2015). Ego pribadi adalah faktor yang menguasai batin pemeriksa BPK saat ia mengalami dilema etis, dimana dalam keadaan dilema itu setan dengan mudahnya masuk lalu membujuk pemeriksa BPK untuk meninggikan kepentingan pribadinya, memperkaya dirinya sehingga akhirnya memutuskan bertindak tidak etis (Noviriani, Ludigdo dan Baridwan, 2018). Oleh karenanya, faktor pribadi pemeriksa BPK adalah kunci sukses dalam pemeriksaan BPK sekaligus penyebab utama terjadinya kecurangan apabila pribadi pemeriksa BPK tersebut tidak memiliki integritas tinggi (Irawan dan McIntyre-Mills, 2016).

Meminimalisir terjadinya efek negative dari ego pribadi tersebut, dibutuhkan kesadaran yang bisa menuntun pribadi pemeriksa BPK agar selalu memutuskan bersikap etis ketika menghadapi dilema etis (Goleman, 2001). Setiap pemeriksa BPK telah berjanji dalam sumpah jabatan mereka didepan 
manusia dan dihadapan Tuhan Yang Maha Esa untuk selalu bertindak etis, karenanya dalam mengemban amanah tersebut, pemeriksa BPK dituntut selalu sadar dan berpedoman pada kode etik dengan berorientasi kuat pada pelayanan publik (public interest) sebagai ciri utama profesi pemeriksa BPK (Briando dan Purnomo, 2019). Untuk mewujudkan kesadaran tersebut dibutuhkan spiritualisme jiwa pribadi pemeriksa BPK yang tinggi dimana hal ini tercermin dengan keyakinan, kerinduan dan kecintaan kuat pada Tuhan, sehingga mendorong pemeriksa BPK agar selalu bersikap baik dalam hidupnya sebagai hamba Tuhan maupun dirinya sebagai pemeriksa dalam dunia profesional (Gupta, 2012). Kesadaran tersebut dapat dikatakan sebagai kesadaran ketuhanan, yang mana adalah kesadaran tertinggi dalam hidup karena pemeriksa BPK menyadari setiap perannya dengan baik dan selalu bertindak etis berdasarkan pemikiran positif. Ter Haar dan Ellis (2006), menegaskan bahwa kesadaran ketuhanan memberikan bimbingan moral sehingga mendorong setiap individu untuk terus memperbaiki kualitas hidupnya.

Kesadaran ketuhanan ini dipengaruhi oleh religiusitas pribadi. Dharmawan (2019) mengartikan religiusitas sebagai sebuah sikap seseorang yang faham dan mau mempraktekkan ajaran agama yang dianutnya dengan sadar. Bagaimana secara sadar orang tersebut memahami, menanamkan dan menyelaraskan norma-norma agama ke dalam pribadinya sehingga membentuk kepribadian mereka yang suci (Purnamasari dan Amaliah, 2015). Stark dan Glock (1965) mengatakan bahwa derajat religiusitas seseorang dipengaruhi oleh tiga aspek penting, yaitu:

1) Cognition, berkaitan dengan pengetahuan ilmu agama dan derajat kepercayaan seorang individu pada nilainilai agama yang dianutnya.

2) Affect, berkaitan dengan kedekatan emosional seorang individu dengan ajaran agama yang dianutnya.

3) Behaviour, berkaitan dengan seberapa sering seorang individu mengunjungi tempat ibadah, membaca kita suci dan melakukan sembayang.

\section{[Figure 2 about here.]}

Berdasarkan pemikiran Stark dan Glock (1965) religusitas akan mempengaruhi moral pemeriksa BPK, bagaimana caranya?

1) Religiusitas tinggi membuat pemeriksa BPK selalu mengingat kehadiran Tuhan saat mendapatkan godaan dan menjadikan benteng bagi dirinya ketika menghadapi dilema etis sehingga pemeriksa BPK tidak terbujuk oleh rayu setan untuk memilih tindak kecurangan karena mereka percaya Tuhan melihat, mengawasi dan tahu setiap perilaku mereka.

2) Religiusitas tinggi membuat pemeriksa BPK memilih menghindari perilaku tidak etis karena takut akan balasan yang diterimanya nanti di alam akherat. Adanya kehidupan kekal setelah kematian di alam akherat yaitu surga atau neraka akan mempengaruhi perilaku etis pemeriksa BPK, jika mereka ingin tinggal disurga yang indah dalam keabadian maka upaya yang harus mereka lakukan di dunia adalah mempertahankan sikap etis ketika dihadang dilema etis.

3) Religiusitas tinggi pemeriksa BPK mendorong kesadaran bahwa bersikap etis adalah perintah agama. Sebagai hamba Tuhan, pemeriksa BPK diperintahkan selalu jujur dan adil baik dalam sikap maupun perbuatan mereka, serta hanya memilih pekerjaan halal sesuai perintah agama.

Seorang pemeriksa BPK dengan religiusitas tingkat tinggi memiliki rasa empati lebih besar dan memperhatikan kepentingan publik diatas kepentingan pribadinya (orientasi pada public interest tinggi). Kepentingan publik yang tinggi menyiratkan bahwa pemeriksa BPK menyadari bahwa tanggung jawab pemeriksaan mereka tidak eksklusif untuk pemberi kerja atau diri mereka saja tetapi juga untuk seluruh stakeholders yang mengandalkan informasi dari Laporan Hasil Pemeriksaan (LHP) mereka. Pamungkas (2014) mengatakan bahwa semakin religius seorang pemeriksa maka semakin rendah kecenderungannya untuk mau terlibat dalam praktik kecurangan, dan dengan religiusitas tinggi pemeriksa BPK maka kualitas moralnya juga akan semakin baik sehingga diharapkan menghasilkan perbaikan serta peningkatan kualitas pemeriksaan BPK yang unggul nantinya.

\section{Upaya Penegakkan Etika Profesional Pemeriksa BPK}

Etika profesi sendiri adalah studi tentang benar atau salah, baik atau buruknya perilaku seseorang dalam menjalanan profesinya (Lamba et al., 2020). Menurut Triani, Hidayat dan Ardianto (2020), etika profesional diciptakan guna memberi pelayanan dan menjamin kepentingan pengguna informasi jasa audit. Berdasarkan pemikiran tersebut BPK membuat etika profesi atau kode etik pemeriksa BPK untuk menjaga kepercayaan masyarakat akan kualitas pemeriksaan pengelolaan keuangan negara yang dilakukannya sebagai bentuk pertanggung jawaban profesinya kepada publik (Ahinful et al., 2017).

Etika berasal dari kata "ethos" dan Moral berasal dari kata "mores", keduanya memiliki arti sama yaitu adat istiadat, dimana ethos berasal dari bahasa Yunani sementara mores berasal dari bahasa Latin (McPhail dan Walters, 2019). Meskipun memiliki persamaan arti, tetapi sebenarnya etika dan moral adalah dua hal yang berbeda. Moral adalah sistem nilai tentang bagaimana manusia hidup dalam adat istiadat kebiasaan yang mewujud dalam suatu kebiasaan, sementara etika merupakan filsafat moral karena memiliki norma dan terkait dengan masalah hidup manusia itu sendiri (Duska, 2007).

McPhail dan Walters (2019) mendefinisikan etika sebagai suatu hal yang dapat dipelajari, melakukan hal yang benar sesuai standar masyarakat, sedangkan moral adalah suatu hal yang muncul dari diri sendiri, mengajarkan apa yang benar atau salah. Dari gagasan tersebut terlihat bahwa etika tidak sama dengan moral, etika berlaku umum untuk masyarakat dan berkaitan dengan budaya baik yang tumbuh di kehidupan masyarkat, sedangkan moral sifatnya lebih pribadi, dimana setiap individu memiliki persepsi benar atau salahnya masingmasing sesuai kepercayaan mereka.

Etika memiliki cakupan yang lebih luas daripada moral dan 
etika dapat dibuat serta dibentuk oleh sebuah organisasi profesi, sepertihalnya BPK RI membentuk kode etik pemeriksa BPK yang berlaku umum untuk semua anggota profesinya dan harus dipatuhi. Semakin baik moral seorang pemeriksa BPK maka ia akan berusaha memberikan pelayanan semaksimal mungkin, bersikap jujur, amanah dan selalu berpedoman pada kode etik dalam menjalankan kewajibannya sehingga membuat masyarakat menaruh kepercayaan tinggi pada mereka (Nikmatuniayah, 2015). Kode etik menjadi dasar pemikiran serta pertimbangan moral bagi pemeriksa BPK dalam memutuskan setiap tindakan atau sikap mereka (Briando, Triyuwono dan Irianto, 2017).

Kesadaran menegakkan etika diharapkan mampu mendorong pemeriksa BPK mencapai tujuan profesi mereka dan juga tujuan akhir yang holistic yaitu menggapi ridho illahi untuk kesuksesan akhirat (Sylvia, 2014). Untuk menegakkan kode etik pemeriksa tersebut, menurut peneliti ada beberapa upaya yang dapat diterapkan oleh pemeriksa BPK yaitu:

\section{Kemampuan Manajemen Moral.}

Etika memiliki konsekuensi logis pada terjadinya degradasi moral jika terus berorientasi pada hasil yang diukur dengan materi atau profit (West, 2018). Sejatinya bagi profesi pemeriksa, moral lebih penting daripada uang atau materi semata yaitu untuk memperoleh ridho sang pencipta dalam hidup ini (Briando, Triyuwono dan Irianto, 2017). Transformasi pemikiran quality over quantity atau fokus pada kualitas adalah yang utama dibandingkan kuantitas (Sikula Sr, 2009). Manajemen moral selanjutnya harus didukung melalui pelaksanaan proses pemeriksaan yang berjalan dengan etis daripada hasil atau profit tinggi sehingga dapat meminimalisir praktik pelanggaran etika.

Pada praktik di dunia profesional dimana pemeriksan BPK sering dihadapkan pada dilema etis karena godaan gratifikasi sebagai balas jasa kecurangan, maka kemampuan manajemen moral akan membawa kesadaran dan memupuk integritas pemeriksa BPK bahwa moral (quality) lebih utama daripada uang atau gratifikasi yang mereka terima (quantity) (Susanto, 2020; Menzel dan White, 2015). Menjunjung tinggi moralitas yang bedasarkan pada kode etik pemeriksa BPK adalah suatu tindakan terhormat dan bermartabat baik dimata tuhan maupun sesama manusia (McGrath, 2017).

Kemampuan seorang pemeriksa BPK mengelola moralitas atau kualitas secara proaktif juga diharapkan dapat memengaruhi lingkungan sekitarnya seperti rekan sejawat, bawahan ataupun bahkan pimpinan untuk memandu dan menjaga mereka agar selalu berperilaku etis dengan terus mengomunikasikan standar etika (Engelbrecht, Heine dan Mahembe, 2017). Oleh karena itu, kemampuan manajemen moral merupakan aspek utama untuk menegakkan kode etik pemeriksa BPK karena dapat mengkonstruksi perilaku etis individu maupun lingkungan sekitarnya (Mayer et al., 2012).

\section{Menjadi Pemeriksa BPK yang Amanah.}

Sifat amanah lekat dengan perspektif Islam karena merupakan salah satu sifat keutamaan Muhammad SAW, dimana sebagai Rasul dalam memenuhi perintah Allah, beliau selalu bersikap penuh tanggungjawab dan jujur untuk membawa pengikutnya menuju kebenaran (Salin, Ab Manan dan Kamaluddin, 2020). Tanggungjawab dan jujur adalah bentuk nurani yang harus dimiliki setiap individu profesional dimana "rasa" tersebut akan membentuk diri untuk selalu bersikap etis serta dekat dengan nilai ketuhanan (Briando, Triyuwono dan Irianto, 2017).

Amanah merupakan kekuasaan atau otoritas yang harus dijalankan dengan penuh amanah juga oleh manusia karena merupakan pendelegasian wewenang dari Tuhan (Briando dan Purnomo, 2019). Otoritas yang diperoleh pemeriksa BPK disadari sebagai wewenang yang diberikan oleh Tuhan kepadanya, sehingga mereka akan dituntut mempertanggungjawabkan segala tindakannya kelak dihadapan Tuhan (Zuhdi, 2014). Oleh karenanya, pemeriksa BPK akan selalu bersikap jujur, independen dan memegang prinsip-prinsip etika sebagai bentuk pertanggungjawaban mereka tidak hanya kepada masyarakat tetapi juga lebih jauh yaitu kepada Tuhan sang pemberi wewenang utama.

Nurani pemeriksa BPK yang dipenuhi dengan sifat amanah akan membuat dirinya menjadi pribadi unggul karena sifat tersebut dapat diimplementasikan di berbagai bidang kehidupan dan tidak terbatas pada profesi semata. Sifat amanah ini akan selalu menuntun sikap pemeriksa BPK menuju kebenaran serta mencegah perbuatan jahat karena memiliki ketenangan jiwa sehingga tidak mudah tergoyahkan oleh syahwat nafsu dunia (Riyadi, 2017).

\section{Memiliki Pengetahuan Hukum Cukup.}

Pemeriksa BPK dengan pengetahuan hukum yang baik diharapkan akan memiliki kesadaran hukum tinggi dan faham akan konsenkuensi hukum apabila memilih berbuat curang. Kesadaran hukum diartikan sebagai kesadaran pribadi pemeriksa BPK tanpa adanya tekanan, paksaan maupun perintah pihak lain untuk taat pada hukum yang berlaku (Noviriani, Ludigdo dan Baridwan, 2018). Taat pada hukum merupakan bagian dari perilaku etis yang bisa melindungi pemeriksa BPK sehingga tidak bertindak bertentangan dengan normal, kode etik, serta aturan pengawasan lainnya dimana secara nyata dilarang oleh hukum (West, 2018). Kemampuan ini akan mendukung penegakkan kode etik dengan menjadi alat kontrol bagi pemeriksa BPK dimana dalam memutuskan setiap tindakannya akan diikuti oleh konsekuensi hukum, sehingga mereka tahu batasan-batasan yang harus dipraktikan.

Sistem hukum Indonesia bersumber $80 \%$ atas nilai-nilai hukum barat sementara $20 \%$ bersumber dari nilai Islam dan adat (Briando, Triyuwono dan Irianto, 2017; Umar, 2014). Persentase tersebut terasa ironi karena nilai-nilai barat tidak mempertimbangkan nilai ketuhanan dan etika sehingga kurang relevan dengan dasar negara kita yang berasaskan Pancasila sebagai sumber dari segala sumber hukum. Nilai ketuhanan sebagai sila pertama dalam Pancasila mengartikan bahwa masyarakat Indonesia wajib percaya pada Tuhan sehingga dalam kehidupan sehari-hari mereka harus mengamalkan ajarannya termasuk kaitannya dengan penegakkan dan 
pembangunan kerangka hukum untuk menggapai ridho illahi (Noviriani, Ludigdo dan Baridwan, 2018). Agar pengetahuan hukum serta kesadaran hukum pemeriksa BPK berjalan optimal, maka setiap pemeriksa BPK harus faham dan menanamkan dalam diri mereka bahwa sumber utama dari semua sumber hukum berasal dari Tuhan, para "oknum" yang berpraktik curang mungkin saja lolos dari hukum dunia, tapi mereka tidak akan pernah lolos dari peradilan hukum Tuhan karena bersifat universal serta berlaku di seluruh alam semesta (Umar, 2014).

\section{Memahami Kode Etik Profesi Secara Komprehensif.}

Kode etik profesi merupakan dokumen legal sebagai pedoman infrastruktur etika dimana didalamnya menjelaskan standar perilaku, tugas, tanggungjawab dan prinsip-prinsip dasar etika yang harus dipenuhi anggota profesinya (IESBA, 2018). Pada kode etik pemeriksa BPK maupun lampiran penjelasannya, batasan-batasan tindakan yang diperbolehkan dan dilarang di deskripsikan secara rinci sehingga selain berfungsi sebagai pedoman, kode etik juga menjadi alat pengendali perilaku pemeriksa BPK (Merchant dan White, 2017). Kode etik pemeriksa BPK dirumuskan dengan menyesuaikan pada waktu, kondisi dan budaya masyarakat Indonesia serta bersifat terbuka atas perubahan, karenanya kode etik ini bukan hanya sebuah simbol dari keberadaan profesi pemeriksa BPK semata melainkan benar-benar mengakomodir kebutuhan pemeriksa BPK secara komprehensif sehingga dapat dipraktikan dalam dunia profesi secara nyata (Constandt, De Waegeneer dan Willem, 2019). Mengetahui dan faham akan bahasan pasal-pasal dalam kode etik tidaklah cukup, pemeriksa BPK harus bisa memaknai substansi isi dari setiap bagian dari kode etik pemeriksaannya dan mempraktekkan setiap perintah kode etik dengan sungguh-sungguh (Jordanova, 2012). Pemahaman komprehensif atas kode etik profesi menjadi kewajiban bagi setiap profesi yang melayani kepentingan pulik, khususnya bagi BPK RI sebagai satu lembaga independen dengan tanggungjawab pemeriksaan akuntabilitas serta transparansi pengelolaan keuangan negara (Edlins, 2019). Implikasi yang diharapkan dari pemahaman komprehensif ini adalah peningkatan kemampuan teknis dan sikap profesional pemeriksa BPK.

\section{Memiliki Kecintaan Pada Alam.}

Cinta akan membawa pribadi pemeriksa BPK berempati dalam banyak hal, termasuk pada kelestarian alam karena kesadarannya akan perintah Tuhan untuk berbuat baik pada sesama makhluk ciptaannya (West, 2018). Selain tanggungjawab pada Tuhan, pemeriksa BPK juga memiliki tanggungjawab pada alam dan keberlanjutan hidup manusia. Tuhan memberikan kekayaan alam melimpah kepada Indonesia untuk diolah sebaik-baiknya demi kemaslahatan hidup masyarakatnya, karenanya pemeriksa BPK sebagai pengawas pengelolaan kekayaan negara berkewajiban ikut serta dalam menjaga kelestarian alam dengan selalu bertindak transparan, obyektif sesuai prinsip-prinsip etika dalam pemeriksaannya terutama saat memeriksa aparat pemerintah atau lembaga yang tugasnya adalah mengelola sumber daya alam Indonesia (Husain, 2015).

\section{Mengenali Setiap Praktik Tidak Etis.}

Potensi seorang pemeriksa BPK beperilaku tidak etis tak terbatas jumlahnya dan dapat dipicu oleh sumber apapun. Individu "baik" sekalipun memiliki kemungkinan untuk berperilaku tidak etis misalnya dengan ketidaksengajaan karena tidak bisa mengenali dan menilai akibat yang ditimbulkan dari tindakannya (West, 2018). Pemahaman berperilaku etis harus lebih jauh daripada hanya sekedar tahu mana hal baik atau buruk, berperilaku etis memiliki implikasi lebih luas, dan tidak terbatas pada hasil akhir atau tujuan dari tindakan tersebut apakah baik atau buruk tapi lebih dari itu yaitu mengetahui manfaat yang ditimbulkan dari setiap tindakannya (Merchant dan White, 2017).

Agar dapat terhindar dari perilaku tidak etis, setiap pemeriksa BPK harus mempelajari setiap praktik perilaku tidak etis agar mereka tahu, kenal, faham dan bisa menilai dengan objektif setiap praktik yang terjadi selama proses pemeriksaan apakah tergolong perilaku etis atau bukan (Brown dan Mitchell, 2010). Mempelajari perilaku tidak etis juga memberi pemeriksa BPK wawasan mengenai alasan atau sebab suatu perilaku tidak etis timbul, bagaimana prosesnya berkembang dan akibatnya, sehingga mereka bisa dengan objektif menilai setiap temuan yang dihadapi selama proses pemeriksaan secara kritis dari sebab, proses, akibat, tujuan dan manfaat suatu tindakan (Hazgui dan Brivot, 2020). Hasil akhir atau outcome mempelajari perilaku tidak etis ini adalah meningkatkan kekayaan kompetensi pemeriksa BPK sehingga pemeriksa tidak mudah dikelabuhi oleh oknum yang berusaha menggoyahkan independensi mereka.

\section{Tidak Berusaha Mencari-cari Kesalahan.}

Pemeriksaan merupakan suatu proses pengidentifikasian masalah, analisa serta evaluasi sesuai standar pemeriksaan BPK guna menilai kebenaran, kecermatan, kredibilitas, serta keandalan informasi pengelolaan maupun tanggungjawab keuangan negara (BPK RI, 2018). Berdasarkan definisi tersebut dalam kode etik pemeriksa BPK jelas ditunjukkan bahwa tujuan pemeriksaan BPK RI bukanlah menemukan masalah atau kesalahan, apalagi "mencari-cari" kesalahan pengelolaan keuangan negara lalu menjadikannya hasil temuan. Tujuan pemeriksaan BPK RI adalah mengidentifikasi masalah yang dihadapi aparat pemerintah maupun lembaga negara dalam praktik pengelolaan keuangan negara, menganalisa bagaimana akar masalah tersebut terjadi lalu memberikan rekomendasi pemecahan masalah, dan terus melakukan evaluasi apakah rekomendasi sudah dijalankan oleh pihak terkait serta telah berjalan efektif.

Setiap pemeriksa BPK harus faham bahwa tugas dan tanggungjawab mereka bukanlah mencari-cari kesalahan pemerintah atau lembaga negara yang diperiksa melainkan memberikan rekomendasi untuk pengelolaan keuangan negara agar lebih efektif, karenanya kode etik pemeriksa BPK berfungsi membantu pemeriksa sebagai dasar tindakan mereka sehingga dapat menemukan, merumuskan dan menjelaskan 
rekomendasi atau solusi terbaik dari setiap temuan hasil pemeriksaannya (Wilopo, Dewi dan Djuwito, 2018). Pemeriksa BPK harus memposisikan diri mereka sebagai advisor eksternal yang independen bagi pemerintah beserta aparatnya sehingga menghasilkan perbaikan pengelolaan keuangan negara.

Segala upaya diatas apabila diterapkan dan terkristalisasi dengan baik dalam pribadi pemeriksa BPK, maka akan memotivasi pemeriksa BPK untuk selalu patuh pada kode etik dan meningkatkan kualitas Laporan Hasil Pemeriksaan (LHP) BPK RI sehingga tercipta pengelolaan keuangan negara secara efektif, efisien maupun transparan. Selain itu, manfaat bagi BPK RI adalah meningkatnya kredibilitas serta kepercayaan publik pada BPK RI khususnya pada profesi pemerika BPK. Demi menjamin bahwa kode etik pemeriksa BPK dapat berfungsi dengan baik, setiap pemeriksa BPK juga harus menyadari bahwa menjadi pemeriksa BPK adalah sebuah profesi bukan pekerjaan karena profesi dan pekerjaan adalah dua hal yang berbeda.

Adanya independensi dan kesadaran akan tanggungjawabnya untuk kepentingan public (public interest) adalah ciri yang menunjukkan suatu profesi. Ketika seorang pemeriksa BPK sudah tidak lagi independen dan tidak lagi berorientasi untuk melayani masyarakat maka dengan mudah praktik kecurangan atau pelanggaran etika terjadi, kasus Ali Sadli dan Rochmadi Saptogiri pada tahun 2017 merupakan contoh lemahnya independensi dan hilangnya public interest, dimana keduanya terbukti menerima suap untuk memberi opini Wajar Tanpa Pengecualian (WTP) pada Laporan Hasil Pemeriksaan (LHP) atas Laporan Keuangan Kemendes tahun anggaran 2016 (Kumparan, 2017). Hilangnya independensi dan oritentasi kepentingan publik pemeriksa BPK, artinya menjadi pemeriksa BPK tidak lagi disebut profesi tetapi berganti menjadi sebuah pekerjaan, karena profesi membutuhkan etika profesional sedangkan pekerjaan tidak. Sebagai, seorang pemeriksa BPK yang profesional menjunjung tinggi serta menjaga independensi dan public interest adalah kewajiban utama yang tidak bisa dikompromikan dan diganggu gugat dalam memenuhi pekerjaannya (Duska, 2007).

\section{KESIMPULAN}

Pemeriksa BPK dituntut menjunjung tinggi prinsip etika yaitu independensi, integritas dan profesionalisme dalam menjalankan fungsi pemeriksaan. Independensi pemeriksa BPK ditunjukkan melalui sikap bebas dan tidak memihak dalam merespon fakta atau temuan, dan juga dalam memberikan rekomendasi hasil pemeriksaan. Pemeriksa BPK yang berintegritas akan bersikap jujur, bekerja keras, tegas dan memiliki kompetensi keahlian yang memadai selama proses pemeriksaan. Profesionalisme pemeriksa BPK diwujudkan melalui praktik skeptisisme profesional yang selalu menerapkan questioning mind selama pemeriksaan dan mengutamakan pertimbangan profesional saat melaporkan temuan pemeriksaannya ke dalam laporan hasil pemeriksaan (LHP).

Tidak mudah mewujudkan prinsip-prinsip etika tersebut dalam praktik pemeriksaannya karena pemeriksa BPK berada dalam lingkungan kompleks dengan beraneka ragam persepsi individu dan juga kepentingan kelompok atau golongan berbeda yang seringkali berupaya menggoyahkan profesionalisme pemeriksa BPK sehingga terjadi dilema etis. Ego pribadi pemeriksa BPK adalah faktor yang menguasai batin pemeriksa BPK saat ia mengalami dilema etis, meminimalisir terjadinya efek negative dari ego pribadi tersebut, dibutuhkan kesadaran ketuhanan yang dibangun dari religiusitas untuk membentuk moral dan kesadaran menegakkan kode etik sehingga menuntun pribadi pemeriksa BPK agar selalu memutuskan bersikap etis ketika dihadapakan pada dilema etis. Religiusitas mempengaruhi moral pemeriksa BPK melalui tiga acara yaitu: pertama, selalu mengingat kehadiran Tuhan sehingga menjadi benteng diri bagi pemeriksa BPK saat mengalami dilema etis; kedua, pemeriksan BPK meyakini adanya kehidupan di alam akherat sehingga mereka memilih terus berperilaku etis agar dapat hidup kekal abadi di surga; ketiga, pemeriksa BPK memiliki kesadaran bahwa berperilaku etis adalah perintah agama sehingga mereka sealu berupaya untuk jujur dan adil baik dalam sikap maupun perbuatan mereka, serta memilih pekerjaan halal sesuai perintah agama.

Upaya yang dapat ditempuh oleh pemeriksa BPK untuk menegakkan kode etik diantaranya yaitu, kemampuan manajemen moral, menjadi pemeriksa BPK yang amanah, memiliki pengetahuan hukum cukup, memiliki pemahaman kode etik profesi yang komprehensif, memiliki kecintaan pada alam, mengenali setiap praktik tidak etis, serta tidak berusaha mencari-cari kesalahan. Segala upaya tersebut apabila diterapkan dan terkristalisasi dengan baik maka akan memotivasi pemeriksa BPK untuk selalu patuh pada kode etik dan meningkatkan kualitas Laporan Hasil Pemeriksaan (LHP) BPK RI sehingga tercipta pengelolaan keuangan negara secara efektif, efisien maupun transparan. Selain itu, manfaat bagi BPK RI adalah meningkatnya kredibilitas serta kepercayaan publik pada BPK RI khususnya pada profesi pemerika BPK. Menjamin bahwa kode etik pemeriksa BPK dapat berfungsi dengan baik, setiap pemeriksa BPK juga harus menyadari bahwa menjadi pemeriksa BPK adalah sebuah profesi bukan pekerjaan, karena itu menjunjung tinggi serta menjaga independensi dan mengutamakan kepentingan publik adalah kewajiban yang tidak bisa dikompromikan dalam pemeriksaan BPK. Ketika independensi dan oritentasi public interest itu hilang, artinya pemeriksa BPK tidak lagi disebut profesi tapi berganti menjadi pekerjaan. Keterbatasan yang dihadapi peneliti yaitu penggunaan data sekunder yang dirasa belum cukup mampu mencakup keseluruhan faktor ataupun aspek yang mungkin mempengaruhi dilema etis pemeriksa BPK di 
praktik nyata pemeriksaannya dengan baik. Menindak lanjuti keterbatasan penelitian tersebut, saran yang diajukan peneliti untuk menjadi perbaikan dalam penelitian selanjutnya adalah penggunaan data primer melalui wawancara langsung dengan anggota atau pemeriksa BPK. Tujuan wawancara ini adalah agar diketahui dengan pasti aspek atau faktor apa saja yang mempengaruhi dilema etis pemeriksa BPK dalam praktik pemeriksaannya. Berdasarkan informasi hasil wawancara tersebut diharapkan dapat dirumuskan upaya atau strategi penegakkan kode etik yang aplikatif serta sesuai dengan permasalahan di praktik pemeriksaan sehingga memotivasi pemeriksa maupun anggota BPK untuk meningkatkan kepatuhan terhadap kode etik pemeriksa BPK demi mewujudkan pengelolaan negara efektif, efisien dan transparan.

\section{REFERENCES}

Ahinful, G. S., Addo, S., Boateng, F. O. Dan Boakye, J. D. 2017. Accounting Ethics And The Professional Accountant: The Case Of Ghana. International Journal Of Applied Economics, Finance And Accounting, 1, 30-36.

Andrade, J. A. 2015. Reconceptualising Whistleblowing In A Complex World. Journal Of Business Ethics, 128, 321-335.

Bilgin, Y. 2017. Qualitative Method Versus Quantitative Method In Marketing Research: An Application Example At Oba Restaurant. Qualitative Versus Quantitative Research, $1-28$.

BPK RI. 2016. Rencana Strategis Badan Pemeriksa Keuangan 2016-2020, Jakarta, Bpk Ri.

BPK RI. 2017. Launching Aplikasi Whistle Blowing System (Wbs) Dan Program Pengendalian Gratifikasi (Ppg) Bpk. Available: Https://Www.Bpk.Go.Id/News/LaunchingAplikasi-Whistle-Blowing-System-Wbs-Dan-ProgramPengendalian-Gratifikasi-Ppg-Bpk.

BPK RI. 2018. Peraturan Badan Pemeriksa Keuangan Republik Indonesia Nomor 4 Tahun 2018 Tentang Kode Etik Badan Pemeriksa Keuangan. Jakarta.

BPK RI. 2019. Accountability For All Menjadi Slogan Bpk Di Berbagai Kegiatan. Available: Https://Www.Bpk.Go.Id/News/Accountability-For-AllMenjadi-Slogan-Bpk-Di-Berbagai-Kegiatan.

Briando, B. Dan Purnomo, A. S. 2019. Etika Profetik Bagi Pengelola Keuangan Negara. Jurnal Akuntansi Multiparadigma, 10, 342-364.

Briando, B., Triyuwono, I. Dan Irianto, G. 2017. Gurindam Etika Pengelola Keuangan Negara. Jurnal Akuntansi Multiparadigma, 8, 1-17.

Brown, J. O., Hays, J. Dan Stuebs Jr, M. T. 2016. Modeling Accountant Whistleblowing Intentions: Applying The Theory Of Planned Behavior And The Fraud Triangle. Accounting And The Public Interest, 16, 28-56.

Brown, M. E. Dan Mitchell, M. S. 2010. Ethical And Unethical
Leadership: Exploring New Avenues For Future Research. Business Ethics Quarterly, 583-616.

Constandt, B., De Waegeneer, E. Dan Willem, A. 2019. Ethical Code Effectiveness In Football Clubs: A Longitudinal Analysis. Journal Of Business Ethics, 156, 621-634.

Creswell, J. W. Dan Poth, C. N. 2016. Qualitative Inquiry And Research Design: Choosing Among Five Approaches, Sage Publications.

Culiberg, B. Dan Mihelič, K. K. 2017. The Evolution Of Whistleblowing Studies: A Critical Review And Research Agenda. Journal Of Business Ethics, 146, 787-803.

Dellaportas, S. 2013. Conversations With Inmate Accountants: Motivation, Opportunity And The Fraud Triangle. Accounting Fórum, 37, 29-39.

Dharmawan, N. A. S. 2019. Etika, Agama, Dan Cinta Sebagai Modal Dasar Akuntan Dalam Memberantas Korupsi. Jia (Jurnal Ilmiah Akuntansi), 3, 17-32.

Duska, R. F. 2007. Contemporary Reflections On Business Ethics, Springer Science \& Business Media.

Edlins, M. 2019. Developing A Model Of Empathy For Public Administration. Administrative Theory \& Praxis, 1-20.

Engelbrecht, A. S., Heine, G. Dan Mahembe, B. 2017. Integrity, Ethical Leadership, Trust And Work Engagement. Leadership \& Organization Development Journal.

Fatemi, D., Hasseldine, J. Dan Hite, P. 2020. The Influence Of Ethical Codes Of Conduct On Professionalism In Tax Practice. Journal Of Business Ethics, 164, 133-149.

Gabrillin, A. 2017. Auditor Bpk Ali Sadli Divonis 6 Tahun Penjara. Available: Https://Nasional.Kompas.Com/Read/2018/03/05/22443921/ Auditor-Bpk-Ali-Sadli-Divonis-6-Tahun-Penjara.

Goleman, D. 2001. Emotional Intelligence: Issues In Paradigm Building. The Emotionally Intelligent Workplace, 13-26.

Gupta, M. 2012. Spiritual Intelligence And Emotional Intelligence In Relation To Self-Efficacy And SelfRegulation Among College Student. 60-69.

Habsy, B. A. 2017. Seni Memehami Penelitian Kuliatatif Dalam Bimbingan Dan Konseling: Studi Literatur. Jurnal Konseling Andi Matappa, 1, 90-100.

Hazgui, M. Dan Brivot, M. 2020. Debating Ethics Or Risks? An Exploratory Study Of Audit Partners' Peer Consultations About Ethics. Journal Of Business Ethics, 1-18.

Hidayat, M. R. 2019. Bpk Serius Terapkan Kode Etik, Sanksi Berat Ancam Pelanggar. Available: Https://Mediaindonesia.Com/Read/Detail/277790-BpkSerius-Terapkan-Kode-Etik-Sanksi-Berat-AncamPelanggar.

Husain, S. 2015. Metafora Amanah Pengelolaan Dana Pihak Ketiga (Dpk) Sebagai Penopang Asset Perbankan Syariah Ditinjau Dari Aspek Trilogi Akuntabilitas (Studi Kasus Pada Pt. Bank Bni Syariah Cabang Makassar). Jurnal Iqtisaduna, 1, 40-64. 
Iesba 2018. Handbook Of The International Code Of Ethics For Professional Accountants.

Irawan, A. B. Dan Mcintyre-Mills, J. 2016. Application Of Critical Systems Thinking To Performance Auditing Practice At The Indonesian Supreme Audit Institution: Issues And Challenges. Systems Research And Behavioral Science, 33, 24-44.

Jamal, K. Dan Sunder, S. 2011. Is Mandated Independence Necessary For Audit Quality? Accounting, Organizations And Society, 36, 284-292.

Jaya, T. E. Dan Irene, C. 2016. Skepticism, Time Limitation Of Audit, Ethics Of Professional Accountant And Audit Quality (Case Study In Jakarta, Indonesia). Review Of Integrative Business And Economics Research, 5, 173-182.

Jensen, M. C. Dan Meckling, W. H. 1976. Theory Of The Firm: Managerial Behavior, Agency Costs And Ownership Structure. Journal Of Financial Economics, 3, 305-360.

Jordanova, E. 2012. The Ethical Code-A Means To Express Ethics And Values In The Organization. Knowledge Society, 5, 59-61.

Korompis, C. W. M. 2018. Pengaruh Aturan Etika Terhadap Kualitas Audit Yang Dimediasi Oleh Pengendalian Mutu (Survei Pada Auditor Bpk Ri). Going Concern: Jurnal Riset Akuntansi, 13.

Kumparan. 2017. Tawar Menawar Temuan Di Kasus Opini Wtp Kemendes-Bpk Terungkap [Online]. Available: Https://Kumparan.Com/Kumparannews/Tawar-MenawarTemuan-Di-Kasus-Opini-Wtp-Kemendes-BpkTerungkap/Full [Accessed].

Lamba, R. A., Seralurin, Y. C., Lamba, A. Dan Pattiasina, V. 2020. The Effect Of Auditor Independence And Ethics On Auditor Professional Scepticism: Its Implications For Audit Quality In Indonesia. International Journal Of Innovation, Creativity And Change, 12, 383-396.

Latan, H., Jabbour, C. J. C. Dan De Sousa Jabbour, A. B. L. 2019. 'Whistleblowing Triangle': Framework And Empirical Evidence. Journal Of Business Ethics, 160, 189204.

Lloyd, H. R. Dan Mey, M. R. 2010. An Ethics Model To Develop An Ethical Organisation. Sa Journal Of Human Resource Management, 8, 1-12.

Mayer, D. M., Aquino, K., Greenbaum, R. L. Dan Kuenzi, M. 2012. Who Displays Ethical Leadership, And Why Does It Matter? An Examination Of Antecedents And Consequences Of Ethical Leadership. Academy of Management Journal, 55, 151-171.

Mcgrath, A. 2017. Dealing With Dissonance: A Review Of Cognitive Dissonance Reduction. Social And Personality Psychology Compass, 11, E12362.

Mckinney, J. A., Emerson, T. L. Dan Neubert, M. J. 2010. The Effects Of Ethical Codes On Ethical Perceptions Of Actions
Toward Stakeholders. Journal Of Business Ethics, 97, 505516.

Mcphail, K. Dan Walters, D. 2019. Accounting And Business Ethics: An Introduction: Routledge.

Menzel, D. C. Dan White, J. D. 2015. Ethics And Integrity In Public Service: Issues And Challenges Donald C. Menzel. The State Of Public Administration. Routledge.

Merchant, K. A. Dan White, L. F. 2017. Linking The Ethics And Management Control Literatures $\mathfrak{z}^{2}$ Advances In Management Accounting. Emerald Publishing Limited.

Miceli, M. P., Near, J. P., Rehg, M. T. Dan Van Scotter, J. R. 2012. Predicting Employee Reactions To Perceived Organizational Wrongdoing: Demoralization, Justice, Proactive Personality, And Whistle-Blowing. Human Relations, 65, 923-954.

Morales-Sánchez, R., Orta-Pérez, M. Dan Rodríguez-Serrano, M. Á. 2019. The Benefits Of Auditors' Sustained Ethical Behavior: Increased Trust And Reduced Costs. Journal Of Business Ethics, 1-19.

Murphy, P. R. Dan Free, C. 2016. Broadening The Fraud Triangle: Instrumental Climate And Fraud. Behavioral Research In Accounting, 28, 41-56.

Nikmatuniayah, N. 2015. Kinerja Dan Etika Pelayanan Sektor Publik Dalam Upaya Meningkatkan Kepercayaan Masyarakat. Jurnal Akuntansi Multiparadigma, 6, 373-384.

Noviriani, E., Ludigdo, U. Dan Baridwan, Z. 2018. Studi Fenomenologi Atas Dilema Etis Auditor Internal Pemerintah. Ekuitas (Jurnal Ekonomi Dan Keuangan), 19, 217-240.

Pamungkas, I. 2014. Pengaruh Religiusitas Dan Rasionalisasi Dalam Mencegah Dan Mendeteksi Kecenderungan Kecurangan Akuntansi. Jurnal Ekonomi Dan Bisnis, 15, 4859.

Pasaribu, P. Y. Dan Briando, B. 2019. Internalisasi Nilai-Nilai Pancasila Dalam Penyusunan Kode Etik Aparatur Pengawas Internal Pemerintah (Apip). Jurnal Ilmiah Kebijakan Hukum, 13, 245-264.

Purnamasari, P. Dan Amaliah, I. 2015. Fraud Prevention: Relevance To Religiosity And Spirituality In The Workplace. Procedia-Social And Behavioral Sciences, 211, 827-835.

Riyadi, A. K. 2017. The Concept Of Man In Ahmad Asrori's Anthropology Of Tasawuf. Journal Of Indonesian Islam, 11, 223.

Salin, A. S. A. P., Ab Manan, S. K. Dan Kamaluddin, N. 2020. Ethical Framework For Directors-Learning From The Prophet. International Journal Of Law And Management.

Seifert, D. L., Sweeney, J. T., Joireman, J. Dan Thornton, J. M. 2010. The Influence Of Organizational Justice On Accountant Whistleblowing. Accounting, Organizations And Society, 35, 707-717.

Sikula Sr, A. 2009. Moral Management Methodology/Mythology: Erroneous Ethical Equations. Ethics \& Behavior, 19, 253-261. 
Sirajudin 2013. Interpretasi Pancasila Dan Islam Untuk Etika Profesi Akuntan Indonesia. Jurnal Akuntansi Multiparadigma, 4, 456-466.

Sitanala, T. F. 2019. Superior Authority And Fraudulent In Procurement Of Goods/Services: The Role Of Code Of Ethics. Tata Kelola Dan Akuntabilitas Keuangan Negara, 5, 139-155.

Stark, R. Dan Glock, C. Y. 1965. The" New Denominationalism". Review Of Religious Research, 7, 817.

Susanto, E. 2020. Does Love Of Money Matter For Innovative Work Behavior In Public Sector Organizations? Evidence From Indonesia. International Journal Of Public Sector Management.

Sylvia, S. 2014. Membawakan Cinta Untuk Akuntansi. Jurnal Akuntansi Multiparadigma, 5, 139-148.

Syukur, Y. S. 2015. Developing Ethical Behaviours At Bpk Through Human Resource Management Practices. Jurnal Tata Kelola Dan Akuntabilitas Keuangan Negara, 1, 157172.

Tatiara, N. H. Dan Astuti, Y. D. 2019. Persepsi Pemeriksa Terhadap Implementasi Kode Etik Di Lingkungan Badan

Pemeriksa Keuangan Republik Indonesia. Jiafe (Jurnal Ilmiah Akuntansi Fakultas Ekonomi), 4, 69-84.

Tepalagul, N. Dan Lin, L. 2015. Auditor Independence And Audit Quality: A Literature Review. Journal Of Accounting, Auditing \& Finance, 30, 101-121.

Ter Haar, G. Dan Ellis, S. 2006. The Role Of Religion In Development: Towards A New Relationship Between The European Union And Africa. The European Journal Of Dlevelopment Research, 18, 351-367.

Triani, N. N. A., Hidayat, W. Dan Ardianto, A. 2020. Akuntabilitas Akuntan Publik Dalam Memenuhi Kualitas Audit. Jurnal Akuntansi Multiparadigma, 11.

Ulum, A. S. 2005. Pengaruh Orientasi Etika Terhadap Independensi Dan Kualitas Audit Auditor Bpk-Ri. Journal Of Accounting And Investment, 6, 74-93.

Umar, N. 2014. Konsep Hukum Modern: Suatu Perspektif Keindonesiaan, Integrasi Sistem Hukum Agama Dan Sistem Hukum Nasional. Walisongo: Jurnal Penelitian Sosial Keagamaan, 22, 157-180.

Wahyudi, M. 2013. Integrity Of The Indonesian Supreme Audit. Integrity, 469.

West, A. 2018. After Virtue And Accounting Ethics. Journal Of Business Ethics, 148, 21-36.

Wibowo, A. 2015. Pengaruh Kode Etik Akuntan, Personal Ethical Philosophy, Corporate Ethical Value Terhadap Persepsi Etis Dan Pertimbangan Etis Auditor (Studi Empiris Pada Kantor Akuntan Publik Di Jakarta). Serat Acitya, 3, 30.

Wilopo, R., Dewi, N. H. U. Dan Djuwito, D. 2018. Faktor Internal Dan Eksternal Dalam Whistle Blower System.
Ekuitas (Jurnal Ekonomi Dan Keuangan), 18, 242-258.

Winata, S. Dan Khomsiyah, K. 2018. Dampak Kode Etik Pada Pengaruh Filosofi Etis Dan Intensitas Etis Terhdadap Pengambilan Keputusan Etis Akuntan Publik. Ekuitas (Jurnal Ekonomi Dan Keuangan), 1, 259-278.

Zuhdi, M. H. 2014. Konsep Kepemimpinan Dalam Perspektif Islam. Akademika: Jurnal Pemikiran Islam, 19, 35-57. 


\section{LIST OF TABLES}

1 Kesukesan dan Kegagalan Penerapan Kode Etik 
TABLE1/Kesuksesan dan Kegagalan Penerapan Kode Etik

\begin{tabular}{l|l}
\multicolumn{1}{c|}{ Kesuksesan } & \multicolumn{1}{c}{ Kegagalan } \\
\hline 1. Tujuan tergambar jelas & Penetapan tujuan yang tidak realistis. \\
\hline 2. Merinci detil kewajiban dan larangan bagi anggota & Kewajiban pelaporan yang terlalu banyak. \\
\hline 3. Sesuai dengan misi organisasi profesi & Mengakibatkan ketidakefektifan organisasi. \\
\hline 4. Terdapat tujuan pragmantis. & Adanya pergantian kepemimpinan. \\
\hline 5. Didukung adanya umpan balik. & Tidak relevan dengan kondisi saat ini.
\end{tabular}

Sumber: Menzel dan White (2015) 


\section{LIST OF FIGURES}

Kesukesan dan Kegagalan Penerapan Kode Etik ............................................................................................. 16

2 Faktor Yang Mempengaruhi Tingkat Religiusitas Individu ............................................................................................ 17 
Figure 1/ Prinsip-prinsip Etika Pemeriksa BPK

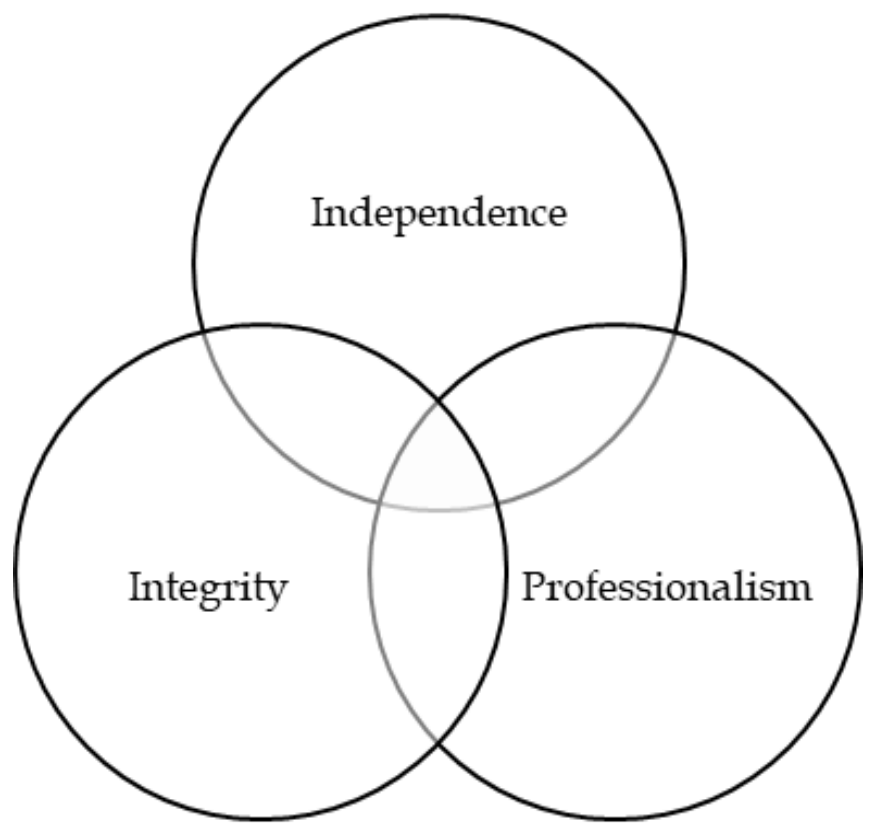

Sumber: Peraturan BPK RI Nomor 4 Tahun 2018

Figure 2/ Faktor Yang Mempengaruhi Tingkat Religiusitas Individu 


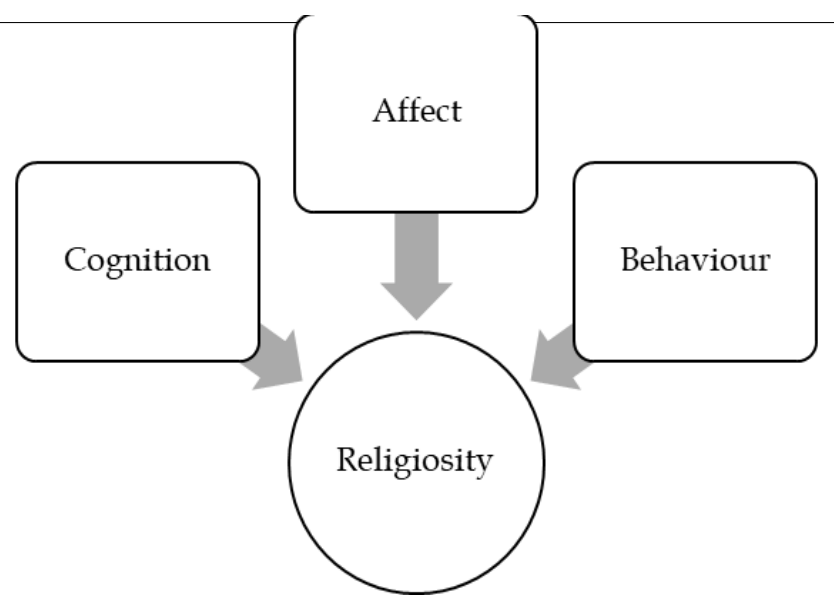

Sumber: Stark dan Glock (1965) 